\title{
تحديات في تطبيق الاعتماد الأكاديمي بالتعليم العالي في المملكة العربية السعودية
} عبدالله نضال عداس

قسم عمار البيئة، كلية العمارة والتخطيط، جامعة الملك عبدالعزيز، جدة، المملكة العربية السعودية aaddas@kau.edu.sa

المستخلص. يشهد التعليم العالي السعودي تغيرات سريعة لمواكبة رؤية المملكة العربية السعودية

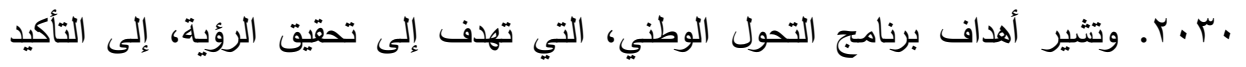

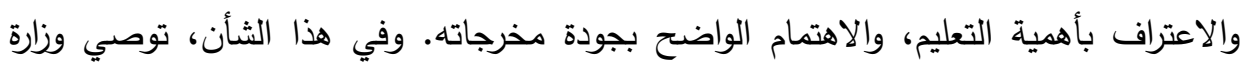

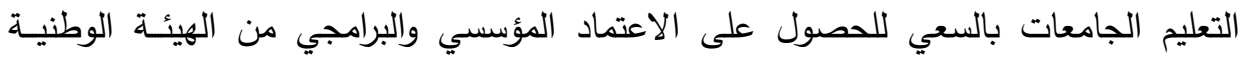

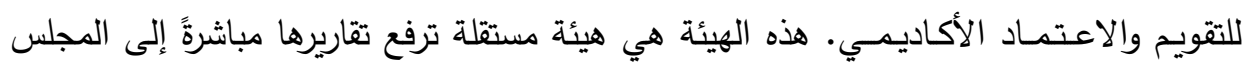

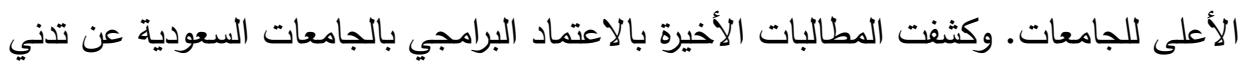

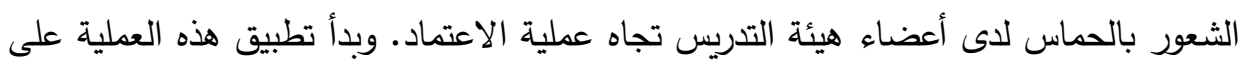

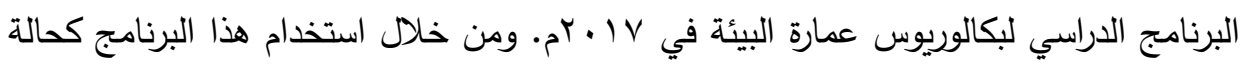

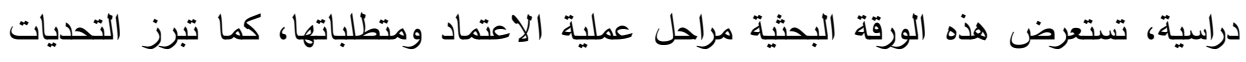

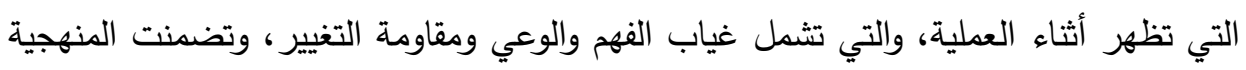

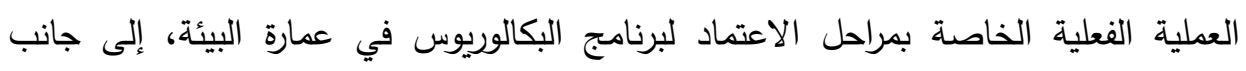

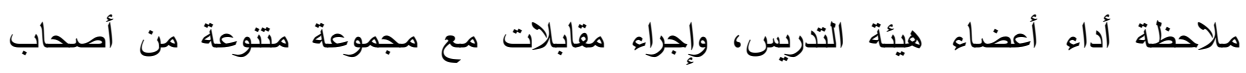

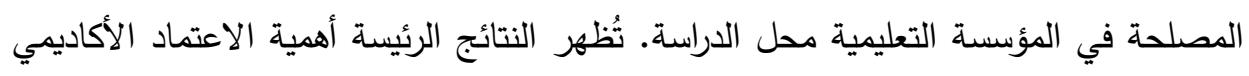

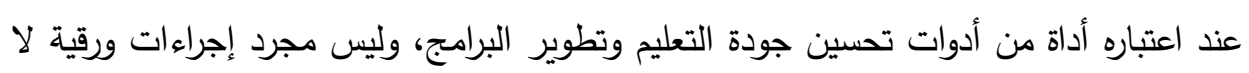

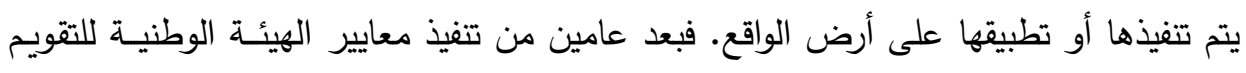

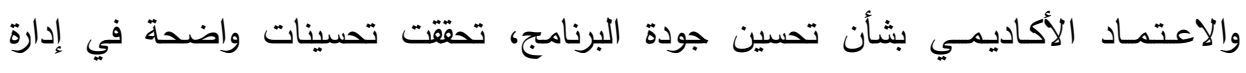

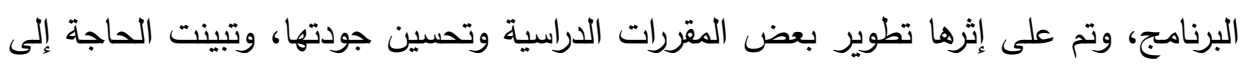

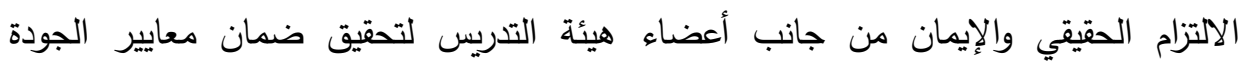

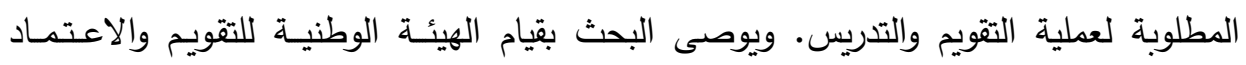

الأكاديمسي بتطوير عملية الاعتماد لتسهيل تطبيقها.

الكلمات الدفتاحية: ضمان الجودة، الاعتماد الأكاديمي، التعليم، المملكة العبية السعودية، 


\begin{tabular}{|l|l|l|l|}
\hline 23. & $\begin{array}{l}\text { Advisory Committee must have been established with a } \\
\text { majority of members in the profession(s) concerned who are } \\
\text { external to the institution. Terms of reference of that } \\
\text { committee must include reviewing program evaluation data } \\
\text { and providing advice on program content and delivery } \\
\text { arrangements. }\end{array}$ & \\
\hline Program KPIs and & $\begin{array}{l}\text { KPIs must have been selected for benchmarking the quality } \\
\text { of the program from the NCAAA proposed KPIs. A list of } \\
\text { KPIs utilized, with benchmarks and analysis must be } \\
\text { available. }\end{array}$ & $\begin{array}{l}\text { Benchmarking } \\
\text { agreement }\end{array}$ \\
\hline 24. & $\begin{array}{l}\text { Program Learning } \\
\text { Outcome Mapping }\end{array}$ & $\begin{array}{l}\text { Mapping the course learning outcomes with the program } \\
\text { learning outcome to ensure it is consistent. }\end{array}$ & Mapping matrix \\
\hline Scales & $\begin{array}{l}\text { The Self-Evaluation Scales for Higher Education Programs } \\
\text { must have been completed with a rating of at least three } \\
\text { stars on all standards and sub-standards applicable to the } \\
\text { program. }\end{array}$ & $\begin{array}{l}\text { NCAAA D2.P } \\
\text { template }\end{array}$ \\
\hline 26. & Self-Study Report & $\begin{array}{l}\text { An initial draft of the SSRP must be submitted. This } \\
\text { includes 11 standards of the NCAAA }\end{array}$ & $\begin{array}{l}\text { NCAAA T12 } \\
\text { template }\end{array}$ \\
\hline
\end{tabular}


Appendix A. NCAAA Program Accreditation Requirements.

\begin{tabular}{|c|c|c|c|}
\hline & Requirement & Discerption & Evidence \\
\hline 14. & $\begin{array}{l}\text { Program } \\
\text { Authorization }\end{array}$ & $\begin{array}{l}\text { The Institution must be authorized to offer the program by } \\
\text { the relevant government authority. }\end{array}$ & Program approval \\
\hline 15. & $\begin{array}{l}\text { Accreditation } \\
\text { Application }\end{array}$ & $\begin{array}{l}\text { There is a need for an agreement between the institution and } \\
\text { the NCAAA that the program is eligible for applying. }\end{array}$ & Agreement letter \\
\hline 16. & $\begin{array}{l}\text { Program } \\
\text { Specifications }\end{array}$ & $\begin{array}{l}\text { This document must be filed by the program coordinator } \\
\text { using the NCAAA template. This document should include } \\
\text { the program mission and vision, learning outcomes, teaching } \\
\text { and assessment methods and other important information } \\
\text { regarding running the program. This document must be } \\
\text { approved by the department board or program steering } \\
\text { committee. }\end{array}$ & NCAAA T4 template \\
\hline 17. & $\begin{array}{l}\text { Course } \\
\text { Specifications and } \\
\text { Reports }\end{array}$ & $\begin{array}{l}\text { A) Course specifications } \\
\text { This document must be filed by each course coordinator (or } \\
\text { course team) using the NCAAA template. This document } \\
\text { should include a course description, topics, learning } \\
\text { outcomes, teaching and assessment methods and other } \\
\text { important information regarding the course such as } \\
\text { textbooks and references. This document must be approved } \\
\text { by the program coordinator and department board. This } \\
\text { document is prepared once and reviewed every five years or } \\
\text { when a major change is made to the course. } \\
\text { B) Course reports } \\
\text { These are corresponding documents to the course } \\
\text { specifications. Student's results, assessment of teaching } \\
\text { methods and learning outcomes and course action plan for } \\
\text { the next year. The completed document must be submitted } \\
\text { every academic semester for every section in the course. }\end{array}$ & NCAAA T6 template \\
\hline 18. & $\begin{array}{l}\text { Course and Program } \\
\text { Requirements }\end{array}$ & $\begin{array}{l}\text { This is the students' guide or program handbook. It should } \\
\text { include program course descriptions and the requirements } \\
\text { for each course - such as prerequisite courses. In addition, it } \\
\text { must include program, department, faculty and institution } \\
\text { regulations and policies. }\end{array}$ & Program handbook \\
\hline 19. & $\begin{array}{l}\text { Annual Program } \\
\text { Report }\end{array}$ & $\begin{array}{l}\text { This is similar to the course report; however, it is the } \\
\text { analysis of the whole course's outcome, teaching strategies, } \\
\text { assessment methods, action plan and issues with course } \\
\text { delivery in the program for the academic year. }\end{array}$ & NCAAA T3 template \\
\hline 20. & $\begin{array}{l}\text { Student Evaluation } \\
\text { Survey Results }\end{array}$ & $\begin{array}{l}\text { Student evaluation surveys must have been conducted with a } \\
\text { minimum of a } 50 \% \text { response rate for all courses. Summary } \\
\text { reports on survey responses must be available for at least } \\
\text { two years by the time the Self-Study Report for Programs } \\
\text { (SSRP) is completed with an action plan. }\end{array}$ & Survey analysis report \\
\hline 21. & $\begin{array}{l}\text { Alumni and } \\
\text { Employer Survey } \\
\text { Results }\end{array}$ & $\begin{array}{l}\text { At least one cohort must have completed the program, and } \\
\text { feedback from that cohort must be available. An Employer } \\
\text { Survey should also be conducted. }\end{array}$ & Survey analysis report \\
\hline 22. & $\begin{array}{l}\text { Program Advisory } \\
\text { Committees }\end{array}$ & $\begin{array}{l}\text { For any program designed to prepare students for } \\
\text { professional practice, a Program, Department or College }\end{array}$ & Meeting minutes \\
\hline
\end{tabular}


Accreditation process for engineering programs in Saudi Arabia: Challenges and lessons learned. In: IEEE Global Engineering Education Conference, EDUCON (pp. 1118-1125). IEEE Computer Society.

[3] Harvey, L. (2004). The Power of Accreditation: Views of Academics. Journal of Higher Education Policy and Management, 26 (2): 207-23.

[4] Ferrara, H. (2007). "Accreditation as a Lever for Institutional Change: Focusing on Student Learning Outcomes." Unpublished PhD Thesis, University of Pennsylvania, Philadelphia.

[5] Stensaker, B. (2003). Trance, transparency, transformation: The impact of external quality monitoring in higher education. Quality in Higher Education, 9(2): 151-159.

[6] Eaton, J. S. (2009). Accreditation in the United States. New Directions for Higher Education, 2009 (145): 79-86.

[7] Proitz, T. S., Stensaker, B. and Harvey, L. (2004). Accreditation, standards and diversity: An analysis of EQUIS accreditation reports. Assessment and Evaluation in Higher Education, 29(6): 735-750.

[8] Dill, D.D. (2000). Designing academic audit. Lessons learned in Europe and Asia. Quality in Higher Education, 6(3): 187-207.

[9] Ulker, N. and Bakioglu, A. (2019). An international research on the influence of accreditation on academic quality. Studies in Higher Education, 44(9), 1507-1518.

[10] Berry, F. J. (1999). "A Comparative Case Study of Accreditation/Program Quality Review in Two Policy Contexts: an International Perspective." Unpublished PhD Thesis, University of Southern California, Los Angeles.

[11] Saurbier, A. L. (2013). “Tacit Quality Leadership: Operationalized Quality Perceptions as a Source of Influence in the American Higher Education Accreditation Process." Unpublished PhD Thesis, Walsh College of Accountancy and Business Administration, Troy.

[12] Addas, A. (2018) Landscape Architecture and the Saudi Arabia Quality of Life Program. Emirates Journal for Engineering Research, 21-29.
[13] Goette, T, Woodard, H, and Young, D. (2008) The Link among Strategic Planning, Curriculum Management, and Assurance of Learning: One School's Experience. Communications of the IIMA, 8(2): Article 4.

[14] Van Lankveld, T., Schoonenboom, J., Volman, M., Croiset, G. and Beishuizen, J. (2017). Developing a Teacher Identity in the University Context: A Systematic Review of the Literature. Higher Education Research and Development. Routledge.

[15] Rahim, S. I., Abumadini, M., Wosornu, L. and Al-Rubaish, A. (2011). Academic job satisfaction questionnaire: Construction and validation in Saudi Arabia. Journal of Family and Community Medicine, 18(1): 1.

[16] Houston, D., Meyer, L. H. and Paewai, S. (2006) Academic staff workloads and job satisfaction: Expectations and values in academe. Journal of Higher Education Policy and Management.

[17] AbdulCader, A. and Anthony, P. J. (2014). Motivational Issues of Faculty in Saudi Arabia. Higher Learning Research Communications, 4(4): 76. https://doi.org/10.18870/hlrc.v4i4.211.

[18] Almuntashiri, A., Davies, M. D. and McDonald, C. V. (2016). The Application of Teaching Quality Indicators in Saudi Higher Education by the Perspective of Academics. Journal of Education and Practice, 7(21): 128-137.

[19] United Nations Development Programme (UNDP). (2003). Arab Human Development Report 2003: Building a Knowledge Society. New York, NY: United Nations Development Program Regional Bureau for Arab States.

[20] Yin, R. K. (2003). Case Study Research: Design and Methods. Thousand Oaks, CA: Sage.

[21] Creswell, J. W. (2007). Qualitative inquiry and research design. Choosing Among Five Traditions (2nd ed.). Thousand Oaks, CA: Sage.

[22] Smit, R. and Birri, T. (2014). Assuring the quality of standards-oriented classroom assessment with rubrics for complex competencies. Studies in Educational Evaluation, 43: 5-13. 
sessions on the importance of accreditation and the program benefits that it can secure.

Involving all faculty members in the academic accreditation process is very important to develop knowledge of the process. This will provide staff with a sense that they are part of decision-making. In addition, it will enhance the working environment in the department and faculty.

Enhancing quality assurance is a series of actions that never stops. This means that academic accreditation is not an end in itself; it is a destination. All academic programs need to keep their program content updated, implement new teaching assessment techniques and produce graduates that will meet market demands. This is the role of the MOE to ensure that programs are improving quality and that academic accreditation is not only a paperwork exercise.

The NCAAA needs to revisit its forms and documents and simplify the language to make it easy to understand. It would also help to provide examples of the forms and evidence to support the programs in understanding the requirements. In addition, the NCAAA requirements are similar for all programs, but the content and level of competences of a design program are totally different from, for example, an Arabic language program. Thus, the NCAAA needs to develop the accreditation process and forms based on the program content.

Lastly, the Ministry of Education and Ministry of Labor need to establish a clear manual that identifies the responsibilities and duties of academic teaching staff.

\section{Conclusion}

All sectors in Saudi Arabia are changing rapidly. The education sector is looking at academic accreditation as a quality assurance tool. The accreditation procedure aims to enhance not only quality control but also the accountability and transparency of the learning process. Programs and institutions must use accreditation as a development tool to encourage the production of actions plans for change and to embed the process into normal business. A range of best practices has highlighted that academic accreditation helps to enhance institutional quality, improve the teaching and assessment methods of faculty members, develop curricula and align learning outcomes with the labor market.

The challenges of academic accreditation in higher education have not been explored through articles and studies. This paper adopted a case study approach that includes observation, unstructured interviews and personal experience to explore the challenges. The paper has set out the themes that emerged from interviews, highlighting the key issues and benefits of accreditation to the BLA program. It was clear that academic accreditation has created a significant improvement to the BLA program at KAU by enhancing the quality of teaching and assessment. In addition, by fulfilling the NCAAA requirements, quality assurance was maintained in the program. On the other hand, resistance within a faculty becomes an obstacle for any program. This occurs where there is a lack the knowledge and staff duties are not clearly identified by the MOE. Future research may explore how to develop the quality of faculty members, especially the older generation, in order to deliver better education. In addition, it is important to note there is a need not only for the procedure that is taking place with the current system but also for tools to measure program quality.

\section{References}

[1] National Transformation Program 2020 (2016). The government of Saudi Arabia, Saudi Vision 2030.

[2] Abou-Zeid, A. and Taha, M. A. (2014). 
achieving NCAAA requirements. The first cohort enrolled in the BLA program in 2014. From then to 2017, there was no clear documentation system for the program, such as course specifications, reports and syllabi. However, two years after implementing the NCAAA standard to enhance the quality of the program, there have been clear improvements, and the majority of courses have a specification, reports and syllabus. Furthermore, the first annual program report was completed in 2019. The program report is considered to be the main tool to improve program administration, courses delivery and quality assurance, and it helped the department and program administration to highlight the action plan needed to deliver improvements. The NCAAA-designed Self-Study Report (SSR) and Self-Evaluation Scales (SES) to help the program identify strengths and weaknesses. The BLA program started working on both the SSR and SES by the beginning of 2019. and this work assisted the department administration in identifying issues and faults that could affect the delivery of the program. These issues were addressed by creating and designing an action plan to enhance the delivery of the program content.

Table 4. BLA Program Accreditation Progress 2017-19.

\begin{tabular}{|l|l|l|}
\hline Requirement & 2017 & 2019 \\
\hline Program Authorization & $100 \%$ & $100 \%$ \\
\hline Accreditation Application & NA & $90 \%$ \\
\hline Program Specifications & $30 \%$ & $87 \%$ \\
\hline Course Specifications & $10 \%$ & $75 \%$ \\
\hline Course Reports and Program & $10 \%$ & $100 \%$ \\
\hline $\begin{array}{l}\text { Course Survey } \\
\text { Requirements }\end{array}$ & $0 \%$ & $90 \%$ \\
\hline Annual Program Report & $0 \%$ & $85 \%$ \\
\hline Student Evaluation Survey Results & $0 \%$ & $100 \%$ \\
\hline $\begin{array}{l}\text { Alumni and Employer Results } \\
\text { Program Advisory Committees }\end{array}$ & $0 \%$ & $100 \%$ \\
\hline Program KPIs & $0 \%$ & $100 \%$ \\
\hline Benchmarks Outcome & $0 \%$ & $100 \%$ \\
\hline $\begin{array}{l}\text { Program Learning } \\
\text { Mapping }\end{array}$ & $0 \%$ & $100 \%$ \\
\hline Self-Evaluation Scales & $0 \%$ & $90 \%$ \\
\hline Self-Study Report & $80 \%$ \\
\hline
\end{tabular}

\section{Recommendations}

Based on interviews, observation and personal experience during the academic accreditation process for the BLA program, this section sets out recommendations to enhance the process and reduce the challenges. These recommendations focus on improving the level of understanding of the teaching staff and to the Authority and NCAAA.
Training faculty members to enhance their knowledge and raise their awareness of accreditation is very important. Preparing NCAAA forms and documents is equally important as they expose issues to faculty members. Course and module design, including learning outcomes, teaching methods and assessment strategies is a significant area of training that should be offered to faculty members. This must include 
shared between faculty and the accreditation body. This is because the design of the NCAAA forms and documents are not clear in language and requirements become difficult to understand the needed information.

\subsection{Resistance to Change}

One of the main issues faced during the preparation for academic accreditation was resistance to change. A minority of faculty members showed their resistance to coping with the wave of change that was taking place in the department and program, which was normal and it was not a threat to the development process. They considered it a burden to improve, and in some cases redesign, their courses because this required renewing and updating their knowledge. This resistance also arose from the need to complete certain activities every academic semester and, as mentioned, the age of teaching staff is an important factor. From observation, some faculty members argued that "assessment of the students' work is not supposed to be according to criteria; the use of a rubric is a waste of time." Despite that, studies show how the use of rubric as an assessment tool is helpful ${ }^{[22]}$. The BLA program depends on assessing students' design projects, artworks and group work. This is not an easy task, and course teachers could be lost between subjectivity and objectivity without clear methods of assessment criteria.

Moreover, the group was resistant to the process of quality improvement and, for three main reasons, considered academic accreditation as an excessive effort. The first reason was the lack of the administrative support needed to provide the academic and teaching staff with training to understand the process and to complete the forms. The second reason was the high teaching load on the academic staff; each staff member needs to fulfil their teaching obligations to gain an allowance on their salary, which is about $25 \%$ of the basic salary. In addition, due to a shortage of teaching staff on the BLA program, the majority are already overloaded, and they have further requirements placed on them, such as membership of committees in the department, faculty and institution, and the need to produce scientific research and participate in conferences and workshops. The third reason was that some of the members do not believe in the process due to a lack of understanding. There is an overlap between these reasons, and the root cause is the absence of training which led to a poor understanding of academic accreditation. However, while it is true that fulfilling the NCAAA requirements is demanding and time-consuming, some sacrifice and commitment are required in serving the community and the country. In addition, there is a need to believe that academic accreditation was designed to enhance and improve the quality of education.

\subsection{Acceptance of the Change}

The clear resistance in 2017 was at a time when the BLA program had not implemented the use of syllabi. However, the majority of courses now have syllabi. In addition, as shown in Table 4, the BLA program achieved a high percentage in most of the requirements because, in most cases, resistance came from a minority. In addition, the involvement of students is very important in academic accreditation. Students in the BLA program noticed that major changes were taking place in both teaching and assessment methods within the program. One of the students stated that "I am happy to see the changes in the department and that most of the faculty members are developing their teaching methods."

\section{Outcomes}

As can be seen from Table 4, it is clear that the BLA program improved in terms of 
building a sense of trust between the program administration and the students is key to securing their cooperation. A KAU faculty member commented: "We created a campaign in the faculty called 'you asked we did' to show our students that we apply their recommendation and suggestions." While academic accreditation is a concern of faculty members, the students are the stakeholders who can perceive changes in the program, which is why their opinions were considered.

\subsection{Documentation and Archiving}

Documentation and archiving are major challenges facing higher education institutions in Saudi Arabia; there is a lack of systems and procedures for all the data regarding programs at the department or faculty levels. However, institutions may have the information required, but it is not easy to access. Based on the interviews, it clear that some program administrators struggle with the availability of basic data, such as "clear student's number in each level", "total number of staff", "numbers of graduates", "annual staff publication" and so forth. This issue means that it takes time to collect information when the program starts preparing the key performance indicators (KPIs). In the case of the BLA program, the committee spent about three months gathering all the data to create KPIs; this is one reason why each step in academic accreditation took longer than expected.

\subsection{Facilities and Equipment}

To have a successful teaching and learning process, there is a need for adequate facilities and equipment to be available for the program; this is one of the key criteria for the NCAAA reviewers. The classrooms and laboratories must be safe and serve the teaching process. One interviewee commented that, "because the provision of faculties in higher education institution is usually separate from the departments", it is usually considered to be a "financial burden" on the institution during the process of the academic accreditation. The department must ensure that the facilities comply with the standards and the Self-Study Report and that the equipment and labs are safe, and students and staff can use it without any harm.

\subsection{Lack of Understanding and Awareness}

The interviews, observation and personal experience revealed a clear misunderstanding of the benefits of academic accreditation. The majority of interviewees considered this process as just added workload to the faculty members. This is due to the absence of training, which would help academic staff to understand the importance of accreditation. One of the participants (LASM) stated that "they should be compensated financially or reduce the teaching load" and another one (FEDSM) indicated that "this is a waste of time and I will teach whatever I want". This is clear evidence that faculty members are not aware of the importance of academic accreditation in enhancing the quality of the teaching and learning process. In addition, the age of the teaching staff plays a critical role. Furthermore, from observation and personal experience, it was clear that there is a knowledge gap between the desired learning outcomes and how to design the related courses and program. A further difficulty was that no-one at the departmental level was able to complete the NCAAA template forms to the desired standard. That is why there was a need for an academic accreditation unit in the LA department. Its members attended workshops to learn how to complete NCAAA documents, identify the proper evidence, design action plans, and write self-study reports. The learning could then be transferred to other members of the department through a series of further meetings and workshops. It is important to note that the challenge of completing documents to the required is 


\begin{tabular}{|c|c|c|c|}
\hline 17 & Assistance professor & Faculty member & Yes \\
\hline 18 & Assistance professor & Faculty member & No \\
\hline 19 & Assistance professor & Head of academic accreditation & No \\
\hline 20 & Assistance professor & Faculty member & No \\
\hline 21 & Associated professor & Member of academic accreditation & Yes \\
\hline 22 & Associated professor & Member of academic accreditation & No \\
\hline 23 & Associated professor & Faculty member & No \\
\hline 24 & Professor & Faculty member & Yes \\
\hline \multicolumn{4}{|c|}{ *Landscape Architecture Department Students } \\
\hline \multicolumn{2}{|c|}{$\begin{array}{l}\text { Level } 4=6 \text { students } / 32 \% \text { of the cohort } \\
\text { Level } 3=7 \text { students } / 58 \% \text { of the cohort } \\
\text { Level } 2=6 \text { students } / 34 \% \text { of the cohort }\end{array}$} & LAS & $19(28 \%)$ \\
\hline
\end{tabular}

\section{Findings and Discussion}

This section highlights the findings from the interviews and the observations on the academic accreditation process in the BLA program. The discussion is presented as seven main themes that give an overview of the problems and challenges faced by the accreditation team; this discussion is followed by recommendations for overcoming these problems and challenges.

\subsection{Team Management}

According to the interviews, building up the academic accreditation committee was a challenge; because of the workload that academic staff faced, it was difficult to devote the time and effort needed. One of the interviewees highlighted this issue, "we need to teach, produce academic and scientific research, and take on administrative roles." It is important to point out that academic staff are not paid extra for duties, such as committee administrative roles. However, the interviews showed that the majority of staff believe that accreditation and the quality assurance of teaching and learning are important.

The academic accreditation team encountered a range of difficulties during the preparations for the process. One of the main issues was that team members were not familiar with the NCAAA forms or how to fill these out, and so it took time to build up knowledge of the NCAAA requirements. In addition, another main concern raised by the majority of the interviewees is that in some cases "a few people tend to join the accreditation committee for personal benefit and they are usually not productive." This issue can lead to other members of the team becoming overloaded and slow the improvement process.

\subsection{Faculty Members and Students Cooperation}

What emerges from the responses is that faculty members are a very important part of the process and of implementing best practice in teaching and assessment. One interviewee noted that "you can have it all on paper but you need the staff to be aware and believe in the accreditation for it to be implemented." The cooperation of faculty members is important on two levels: To complete the process and to implement change in practice. However, as shown below, there was resistance by a few staff members.

In regard to student cooperation, the main challenge was that students tended not to take the questionnaires very seriously. This is a major concern because the change process must be based on evidence. The interviews with the BLA program students suggested that they start taking the process seriously when it touches on improvements to program teaching, assessment and management. In addition, 


\begin{tabular}{|l|l|l|}
\hline Program Advisory Committees & Program Coordinator & Two meetings per academic year \\
\hline Program KPIs & Program Coordinator & Annually \\
\hline Benchmarks & Program Coordinator and Department Head & Annually \\
\hline Program Learning Outcome Mapping & Program Steering Committee & $\begin{array}{l}\text { Every 5 years or on major changes to the } \\
\text { program content }\end{array}$ \\
\hline Self-Evaluation Scales & Program Committees & Every academic accreditation cycle \\
\hline Self-Study Report & Program Committees & Every academic accreditation cycle \\
\hline
\end{tabular}

\section{Methodology}

To explore the accreditation process, a case study research methodology was employed, which included a qualitative approach; case studies provide helpful support to social science studies ${ }^{[20]}$. According to Creswell (2007), this method also assists in understanding participants' points of view, given their life experience. Observations during the BLA program accreditation process and the different workshops and seminars attended and conducted, along with information collected on how to prepare for NCAAA accreditation, were all utilized to identify the challenges and opportunities of academic accreditation ${ }^{[21]}$. In addition, looking at different international and national accreditation procedures helped to identify best practice that could be applied in Saudi Arabia.

Unstructured interviews were conducted with 24 different faculty members and 19 students at King Abdulaziz University to gain their input regarding the difficulties they faced during the accreditation process (Table 3). Challenges and opportunities were identified from the actual process of preparing NCAAA documents and follow-up work, as well as from subsequent seminars and workshops held with faculty members to assist in the process and provide needed support.

Table 3. Interview Details.

\begin{tabular}{|c|c|c|c|c|}
\hline & Code & Academic degree & Administrative position & $\begin{array}{l}\text { Academic accreditation responsibility } \\
\text { (university, faculty, department) level }\end{array}$ \\
\hline \multicolumn{5}{|c|}{ Landscape Architecture Department Staff Members } \\
\hline 1 & \multirow{4}{*}{ LASM } & Assistance professor & Design studio coordinator & Yes \\
\hline 2 & & Assistance professor & Course coordinator & No \\
\hline 3 & & Associated professor & Course coordinator & Yes \\
\hline 4 & & Assistance professor & Course coordinator & No \\
\hline \multicolumn{5}{|c|}{ Faculty of Environmental Design } \\
\hline 5 & \multirow{7}{*}{ FEDSM } & Assistance professor & Head of academic accreditation & Yes \\
\hline 6 & & Assistance professor & Head of academic accreditation & Yes \\
\hline 7 & & Assistance professor & Department head & No \\
\hline 8 & & Assistance professor & Department head & Yes \\
\hline 9 & & Assistance professor & Member of academic accreditation & Yes \\
\hline 10 & & Assistance professor & Design studio coordinator & Yes \\
\hline 11 & & Assistance professor & Course coordinator & Yes \\
\hline \multicolumn{5}{|c|}{ Deanship of Quality \& Academic Accreditation } \\
\hline 12 & DQAA & Assistance professor & Member of the Deanship & Yes \\
\hline \multicolumn{5}{|c|}{ King Abdulaziz faculty members } \\
\hline 13 & \multirow{4}{*}{ KAUSM } & Assistance professor & Faculty vice-dean & Yes \\
\hline 14 & & Assistance professor & Department head & Yes \\
\hline 15 & & Assistance professor & Head of academic accreditation & Yes \\
\hline 16 & & Assistance professor & Faculty member & Yes \\
\hline
\end{tabular}


steps are needed to enhance education quality and meet NCAAA requirements. It is important to note that the NCAAA demands transparency and clarity in all that is submitted.

\subsection{Program Accreditation Eligibility Requirements}

In order for an academic program to apply for NCAAA accreditation, the institution itself must be accredited by the NCAAA. The program must fulfill 13 requirements to become eligible to apply for accreditation. A summary of these 13 requirements is shown in Table 1, and further detail is provided in Appendix A.
Each of the requirements listed in the table above is usually allocated to program internal committees, course coordinators, program coordinators or department heads according to the requirements of each task. The Self-Study Report is the most demanding element because it requires time and awareness regarding practices in both the administrative and academic sides of the $\operatorname{program}^{[2]}$.

The responsibility for each of the requirements is shared between a range of bodies and internal entities within the department. Table 2 sets out who was responsible for each requirement and the timescale involved.

Table 1. Requirements summary.

\begin{tabular}{|l|l|l|}
\hline & Requirement & Evidence \\
\hline 1. & Program Authorization & Program approval \\
\hline 2. & Accreditation Application & Agreement letter \\
\hline 3. & Program Specifications & NCAAA T4 template \\
\hline 4. & Course Specifications and Reports & NCAAA T6 template \\
\hline 5. & Course and Program Requirements & Program handbook \\
\hline 6. & Annual Program Report & NCAAA T3 template \\
\hline 7. & Student Evaluation Survey Results & Survey analysis report \\
\hline 8. & Alumni and Employer Survey Results & Survey analysis report \\
\hline 9. & Program Advisory Committees & Meeting minutes \\
\hline 10. & Program KPIs and Benchmarks & List of KPIs, benchmarking agreement \\
\hline 11. & Program Learning Outcome Mapping & Mapping matrix \\
\hline 12. & Self-Evaluation Scales & NCAAA D2.P template \\
\hline 13. & Self-Study Report & NCAAA T12 template \\
\hline
\end{tabular}

Table 2. Accreditation Responsibilities and Frequency.

\begin{tabular}{|l|l|l|}
\hline Requirement & Responsible & Frequency \\
\hline Program Authorization & Dean's office & One time task \\
\hline Accreditation Application & Dean's office & One time task \\
\hline Program Specifications & Program Coordinator & $\begin{array}{l}\text { Every 5 years or on major changes to the } \\
\text { program content }\end{array}$ \\
\hline Course Specifications & Course Coordinator & $\begin{array}{l}\text { Every 5 years or on major changes to the } \\
\text { program content }\end{array}$ \\
\hline Course Reports & Course Instructor & Every semester \\
\hline Course and Program Requirements & Program Coordinator & One time task \\
\hline Annual Program Report & Program Coordinator & By the end of every academic year \\
\hline Student Evaluation Survey Results & Program Coordinator & Every academic accreditation cycle \\
\hline Alumni and Employer Survey Results & Student Affairs Committee & Annually \\
\hline
\end{tabular}


documents to the NCAAA, including the following:

- Self-study report and self-evaluation scales

- Statistical data

- Program files (specification and report)

- Key Performance Indicators

- Results of three questionnaires: The program evaluation questionnaire, the course evaluation questionnaire, and the learning experiences questionnaire. In addition, the program can provide other types of questionnaire, such as a graduate survey and a students' learning experience survey.

On receipt, the NCAAA registers the documents and transfers them to the competent deputy. A consultant is assigned to review the documents to make sure they are complete and verify that the program is eligible for accreditation.

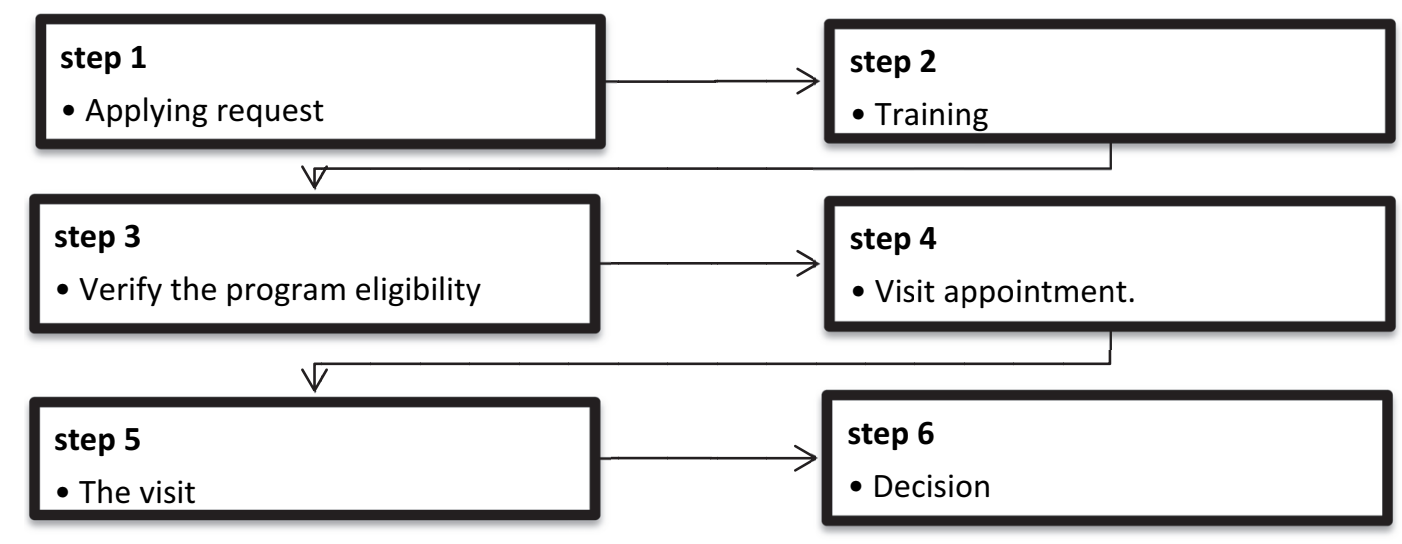

Fig. 1. Accreditation Process Steps.

- Step 4: An appointment is made with the institution and program for visits by NCAAA specialists. The Accreditation Coordinating Committee selects audit teams for programs, and the Auditors Unit sends invitations and coordinates with the auditors. The NCAAA handles all the logistics for the program review.

- Step 5: The actual visit to review the program takes place. Two or three reviewers are assigned, depending on the size of the program. The visit takes 2 to 3 days. The team is usually accompanied by an NCAAA public relations officer to manage logistics and an employee from the accreditation department to coordinate and supervise the review process. The reviewers submit their reports to the
NCAAA with a full visit report and standards compliance table, along with evaluation metrics, which enable the reviewers to quantify each review, contribute to the judgment on the program, help in comparisons, and extract various statistical data and reports.

- Step 6: The consultation team reviews the auditors' reports for consistency and credibility and makes recommendations to the Executive Director to announce the decision, which is full accreditation, conditional accreditation or rejection.

Every step includes a set of requirements that need to be met and supported by evidence. In some cases, guidance will be issued on what 
academic institutions is usually carried out by academic teaching staff at the department or program level. Hence, the duties and responsibilities of the academic staff need to be clear and to describe their roles in detail ${ }^{[14][15][16]}$.

However, in Saudi Arabia, the rules and regulations for faculty member's duties are not identified in any detail with respect to academic accreditation. These rules and regulation were produced in 1996 and, while they are very flexible, there is no clear description of the duties and responsibilities of faculty members in Saudi universities. This situation has led to differences of opinion about the roles of faculty members in positions of academic or administrative responsibility. According to AbdulCader and Anthony (2014), faculty members in Saudi universities suffer from a lack of recognition and moral support. In addition, there is a clear absence of monetary and non-monetary incentives ${ }^{[17]}$.

Regardless of the regulations for faculty member duties, a fundamental problem lies in the quality of teaching in Saudi Arabia ${ }^{[18]}$. The United Nations Development Program (UNDP) 2003 report highlighted the poor quality of education in Arab higher education institutions. The report indicated that the frameworks needed to improve the quality of academics or the development of required teaching capabilities are weak ${ }^{[19]}$. However, recognizing the importance of investing in human capital and enhancing the teaching quality, KAU has taken the initiative by establishing the Center for Teaching and Learning Development (CTLD). The CTLD offers new Saudi teaching staff a professional development diploma for university instructors to enhance both their teaching and assessment methods and their strategies.

\section{The Process and Requirements of Accreditation}

\subsection{NCAAA Accreditation Process}

The NCAAA, like most accreditation centers around the world, has adopted specific requirements that must be met by any educational institution applying for program accreditation. In addition, the NCAAA must be satisfied that the eligibility requirements are met before any program can submit a formal accreditation application. These requirements depend on major elements of the quality assurance standards and the extent of compliance with the statutory requirements that were set out when the applicant secured the right to operate as an institution of higher education.

Program accreditation involves the completion of NCAAA documentation and templates supported by evidence of practice within the program. After submission, an independent external review is undertaken by experts in teaching and qualified assurance methods. There are six major steps involved in the accreditation process (Fig. 1).

- Step 1: The program applies for accreditation by establishing communication with the NCAAA through the institution, usually via the Deanship of Quality and Academic Accreditation (DQAA). The DQAA ensures that the program is eligible to apply by reviewing its documents and evidence to check that NCAAA standards are met.

- Step 2: The NCAAA offers up to two training workshops for program administrators based on their needs and required areas of questioning. The topics are determined according to the needs of the program.

- Step 3: This is a very important step because it verifies program eligibility for accreditation. The program sends the basic 
In regard to the process of academic accreditation in higher education in Saudi Arabia and other countries, the requirements and evidence needed are similar to some extent and include students' evaluation of the learning quality, courses reports and files, and $\mathrm{KPIs}^{[7]}$. However, comparing the NCAAA process with ABET, which is designed for engineering and technology programs, we find out that the NCAAA process is more detailed and complex ${ }^{[2]}$.

\subsection{Landscape Architecture Program}

Landscape architecture (LA) programs in Saudi Arabia are very rare; among 43 public and private universities, only two offer a bachelor's degree in landscape architecture (BLA). However, the LA profession is in high demand because this much-needed field has connections to the majority of the Vision 2030 goals, such as enhancing the quality of life ${ }^{[12]}$. The LA department administration took the initiative to seek accreditation to enhance the quality of education outcomes and meet the NCAAA requirements, making this the first accredited LA program in the country. Accreditation gives the department and the institution greater clarity over the quality of the BLA program and how it serves communities and the country. Furthermore, accreditation ensures that there is a linkage between the program and department strategic plans and the growth of the department ${ }^{[13]}$.

The BLA is a 4-year program offered by the LA department since 2015; it evolved from the previous 5-year Bachelor of Science in Landscape Architecture program. The department has 20 faculty members, mostly from Saudi Arabia (associated professor, assistance professor, lecture and teaching assistance). The numbers vary because some faculty members provide consultancy to government agencies, while others work abroad to build postgraduate experience.
When this study was conducted, 126 students were enrolled, in four main cohorts representing the four years of study. The students are expected to complete 155 credits to graduate from the program. These credits are divided between university courses (26 credits), faculty courses (36 credits), program compulsory courses (70 credits), program elective course (16 credits) and university free course ( 7 credits).

There are 24 compulsory courses divided into four levels: First year (4 courses), second year ( 8 courses $)$, third year ( 8 courses) and the final year ( 4 courses). In addition, the program has 17 elective courses giving 43 credits, of which students are expected to take only 16 credits.

Until the end of 2017, there was no committee responsible for academic accreditation of the BLA program. In 2018, the department set up a committee with responsibility for fulfilling the NCAAA requirements. The committee started with four faculty members and, by the beginning of the 2019 academic year, the committee numbered eight members.

\subsection{Research Question}

The research problem that this study set out to examine was to understand the challenges and opportunities that became apparent during the accreditation process with a view to recommending how the accreditation process can be used effectively as a quality enhancement tool.

\section{Faculty Members in Saudi Arabia}

This section briefly describes the duties and responsibilities for academic teaching staff and teaching quality as they play an important role in accreditation and program quality assurance. According to Harvey (2004), the preparation of documents for academic accreditation and meeting requirements in all 
enhance the quality of academic programs in all private and governmental universities in Saudi Arabia ${ }^{[2]}$.

The NCAAA was formed in 2003 and was at the time under the jurisdiction of the Ministry of Higher Education. However, since 2018, the NCAAA (now the National Center for Academic Accreditation and Evaluation, NCAAE) has been under the Education Evaluation Commission, which was established by Royal Decree in that year. The Commission is responsible for Saudi universities, and its main aims are to raise the quality of educational outcomes, the proficiency of universities and their contribution to developing the economy.

Academic accreditation can be applied to programs or institutions, but there are slight differences in the process; in general, accreditation maintains quality and legitimacy for both the program and the institution ${ }^{[3]}$. Program accreditation covers the quality of education provision and ensures that learning outcomes are achieved through a range of procedures. However, according to Ferrara (2007), while a program benefits when it is accredited, quality assurance cannot be achieved if faculty members do not apply the quality standards in the teaching and learning process $^{[4]}$.

Academic accreditation consists of a set of procedures to gather evidence to ensure that the program or institution is fulfilling the quality standards of the teaching and learning process $^{[5]}$. According to Harvey (2002), the methods of gathering the evidence overlap with methods used in audits, assessments and external examination. The component methods include self-evaluation, data and surveys analysis, key performance indicators, mock visits, and students, staff, alumni and employer survey analysis,s and recommendation. While accreditation is distinct from audit, there is a degree of overlap in the objectives and methods of these different external processes ${ }^{[4]}$ [5].

Every country around the world has its national body for academic accreditation and quality assurance, such as the Quality Assurance Agency for Higher Education (QAA) in the UK and the Tertiary Education Quality and Standards Agency in Australia (TEQSA). In the United States, academic accreditation has four main roles ${ }^{[6]}$ : Providing quality assurance to students and the public; allowing access to federal and state funds; engendering confidence in the private sector in higher education; and helping students to transfer between different institutions ${ }^{[6]}$.

In Eastern Europe, academic program accreditation centers on control and ensuring quality standards by way of the external system. In addition, unsatisfactory auditors' reports might lead to the closure of a program or institution by the accreditation body ${ }^{[4]}$. In the 1990s, European educational policy bodies conducted systematic evaluations of higher education institutions to ensure quality ${ }^{[7]}$. In addition, the internationalization of higher education led to increased awareness of the need to secure the quality of education in Europe $^{[8]}$.

According to Ulker and Bakioglu (2019), academic accreditation has a direct influence on the quality of the academic content, and it leads to improvements in the quality assurance processes in a program or institution $^{[9]}$. In terms of academic accreditation's contribution to quality, previous research conducted by Berry (1999), Ferrara (2007) and Saurbier (2013) showed that the accreditation of a program and institution can play an important role in enhancing the learning and teaching process $^{[4][10][11]}$. 


\title{
Challenges in Implementing Academic Accreditation in Higher Education in Saudi Arabia
}

\author{
Abdullah Nidal Addas \\ Department of Landscape Architecture, Faculty of Architecture \& Planning, King Abdulaziz \\ University, Jeddah, Saudi Arabia
}

Aaddas@kau.edu.sa

\begin{abstract}
Higher education standards in Saudi Arabia are changing rapidly to align with the country's 2030 vision. There is recognition of the importance of education and a clear focus on the quality of education in the objectives of the country's National Transformation Programs which aim to realize that vision. In this regard, the Ministry of Education (MOE) advises universities to obtain both institutional and program accreditation through the National Commission for Academic Accreditation and Assessment (NCAAA), an autonomous body that reports directly to the Council of Higher Education. The recent demand for program accreditation in Saudi universities revealed a lack of enthusiasm among faculty members because of the accreditation process. The Bachelor of Landscape Architecture (BLA) program at King Abdulaziz University began the process in 2017 . Using the program as a case study, this paper outlines the process and its requirements. In addition, the paper emphasizes the challenges faced during the process, which include a lack of understanding and awareness, as well as resistance to change. The methodology included the actual process for the BLA program, with observation and unstructured interviews with faculty members. The main findings indicate the importance of academic accreditation when it is considered as a tool for enhancing education and program quality, rather than just being additional paperwork and written procedures that are not implemented. Two years after implementing the NCAAA standard to enhance the quality of the program, there have been clear improvements in program administration, course delivery and quality. It is evident that there is a need for real commitment and belief in the value of accreditation from all faculty members if improvements are to be achieved. It is recommended that the NCAAA helps by developing the accreditation process to make it easier to follow.
\end{abstract}

Keywords: Quality Assurance, Academic Accreditation, Education, Saudi Arabia, Challenges.

\section{Introduction}

\subsection{Academic Accreditation}

Since the announcement of Vision 2030 in Saudi Arabia, the Ministry of Education (MOE) has maintained its strategic plan to align with the country's vision and objectives, recognizing the importance of education to the country's long-term development. The education sector plays an essential role in enhancing the social structure, linked to the needs of the national economy; the education of the community will produce creative minds, skilled human capital and, ultimately, a productive nation. The government considers the education system as a safe and reliable partner in delivering Vision $2030^{[1]}$.In addition, one of the objectives is the alignment of educational outcomes with the labor market to ensure that Saudi universities meet market demands. This is why MOE considers academic accreditation by the National Commission for Academic Accreditation and Assessment (NCAAA) as a key tool to 